\title{
Evidence of Low Chloroplast Genetic Diversity in Two Carpinus Species in the Northern Balkans
}

\author{
Mihaela Cristina CĂRĂBUŞ ${ }^{1}$, Alexandru Lucian CURTU ${ }^{1}$, \\ Dragoş POSTOLACHE ${ }^{2}$, Elena CIOCÎRLAN ${ }^{1}$, Neculae ŞOFLETEA $^{1 *}$ \\ ${ }^{1}$ Transilvania University of Brasov, Department of Forest Sciences, 1 Şirul Beethoven, 500123, Braşov, Romania; \\ carabus_mihaela88@yahoo.com; lucian.curtu@unitbv.ro; ciocirlan.elena@unitbv.ro;nic.sofletea@unitbv.ro (*correspondingauthor) \\ ${ }^{2}$ National Research and Development Institute in Forestry "Marin Dracea", 65 Horea Str., 400275 Cluj-Napoca, \\ Romania;dragospostolache@yahoo.com
}

\begin{abstract}
Genetic diversity and differentiation in two Carpinus species (C. betulus and C. orientalis) occurring in Romania was investigated by using three chloroplast Simple Sequence Repeat markers (cpSSRs). A total of 96 and 32 individuals were sampled in eighteen $C$. betulus and six C. orientalis populations, respectively. A total of four chloroplast haplotypes were observed. Two haplotypes were specific for C. betulus and two for C. orientalis. Most of C. betulus populations were fixed for the predominant haplotype $(\mathrm{H} 1)$, which was observed in $82 \%$ of the individuals. All C. orientalis populations were fixed for one haplotype or the other. Populations with haplotype (H3) are spread in southern Romania and the haplotype (H4) was observed at the northern limit of $C$. orientalis natural distribution range. Genetic differentiation among populations was moderate in $C$. betulus $\left(G_{S T}=0.422\right)$, compared to the high value observed in $C$. orientalis $\left(G_{S T}=1.000\right)$, which can be explained by the occurrence of a distinct haplotype in the peripheral population. $R_{S T}$ values for both species suggest low levels of recurrent gene flow through seeds among populations. Our data on geographic distribution of chloroplast DNA haplotypes may be useful for the identification and conservation of distinct genetic resources of the two Carpinus species.
\end{abstract}

Keywords: Carpinus betulus, C. orientalis, cpSSR, genetic diversity, phylogeography

\section{Introduction}

Genetic diversity is essential for species to evolve and to adapt to changing environmental conditions. Patterns of genetic diversity are influenced by population contractions and expansions during glacial-interglacial fluctuations and by post-glacial migration history (Petit et al., 2005). Phylogeographic studies have provided important evidence on species demographic history and population structure (Petit et al., 2005; White et al., 2007; Xu et al., 2015) revealing that species-specific life history traits and geographic barriers may have a strong influence on the current patterns of population genetic structure (OrtizRamírez et al., 2016).

The genus Carpinus (Betulaceae family) is represented by two species in Europe ( $C$. betulus L. and $C$. orientalis Mill). European hornbeam $(C$. betulus L.) is a temperate hardwood species especially in forests dominated by oak species, where it demonstrates a great ability to compete with oaks at the juvenile stage (Petre et al., 2012). In Romania C. betulus occupies around $4.8 \%$ of the total forest cover (IFN, 2012). This species is spread between 100 and 450 (500) $\mathrm{m}$ altitude, being rare in mixed beech-fir-spruce mountain forests (Horeanu, 1996). C. betulus is considered as a valuable species due to its strong ecological adaptability and increased tolerance to environmental stress, especially in extreme conditions (Șofletea and Curtu, 2007). C. orientalis is a major pioneer species in arid regions where it can colonise open and degraded areas (Bergmeier and Dimopoulos, 2008; Čarni et al., 2009). Both species cooccur in southeastern Europe and no natural hybrids between $C$. betulus and $C$. orientalis have been reported; however, controlled crosses indicated that hybrids had inferior survival and growth characteristics, and that adult hybrids were sexually immature (Santamour, 1995; Grivet and Petit, 2003). The northern edge of $C$. orientalis distribution range is the southern part of Romania, but isolated small populations are also present in the northern part of the Moldova region (Şofletea and Curtu, 2007). Most of $C$. orientalis populations in Romania can be considered as marginal populations and their genetic diversity assessment is of great importance, due to ongoing global warming. 
Genetic variation of $C$. betulus and C. orientalis have been investigated with different DNA markers targeting different polymorphic regions of the chloroplast genome by PCR-RFLP (Restriction Fragment Length Polymorphism) (Postolache et al., 2017) and also by using chloroplast microsatellites (Simple Sequence Repeats; cpSSRs) (Grivet and Petit, 2003; Fărcaş et al., 2006). The chloroplast DNA diversity for $C$. betulus was significantly lower in western Europe compared with southeastern European populations, that harbour nearly all genetic variation and consequently a more detailed analyses in this region is absolutely necessary to quantify the genetic structure and diversity. Beside this, previously published results Petit and Grivet (2003) indicate for very low introgression between these two species. The $C$. betulus populations from Romania have a very distinct Holocene postglacial history with direct consequences on current genetic pattern that needs to be investigated further in order to understand the species diversity and evolutionary history (Grivet and Petit, 2003; Fărcas et al., 2006). Moreover, the phylogeographic data on $C$. orientalis are very scarce and these data are very important in the conservation and management of this drought-tolerant woody species.

The aim of this study was to analyse the chloroplast DNA variation in two sister species of hornbeam $(C$. betulus and $C$. orientalis) in Romania (Northern Balkan Peninsula) using cpSSRs markers, that can bring detailed information on species genetic structure, which could be applied in developing site-oriented conservation strategy and sustainable management of Carpinus spp. genetic resources. The major objective of this work is to characterize the genetic structure of Carpinus spp. in Romania and to test weather Carpathian Mountains acted as a major geographic barrier during the Holocene postglacial recolonization history. More specifically we aimed: i) to assess the chloroplast DNA genetic variation within and among Carpinus spp. populations using cpSSRs; ii) to analyse the geographic distribution of chloroplast haplotypes and infer direct consequences on the management and conservation of Carpinus spp. genetic resources.

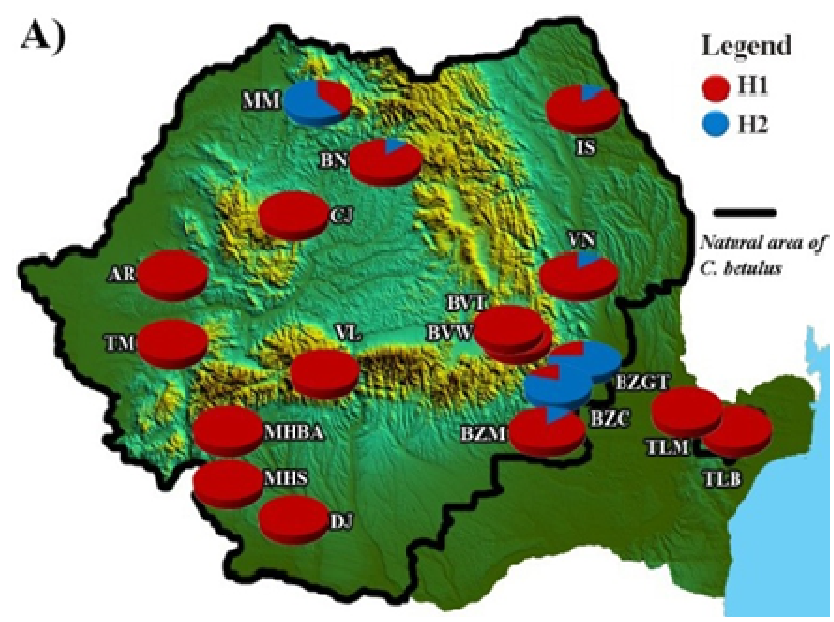

\section{Materials and Methods}

\section{Sampling and DNA isolation}

Shoots and leaves were collected from 18 populations of C. betulus and six populations of $C$. orientalis covering the species distribution range in Romania (Table 1, Fig. 1). The material was stored in an ultrafreezer at temperatures of $-60^{\circ} \mathrm{C}$ until used for DNA extraction.

Genomic DNA was extracted from biological specimens using the CTAB method described by Doyle and Doyle (1987) with minor modifications. The DNA was quantified using NanoDrop 8000 (Thermo Scientific, Wilmington, USA, 2008) and extracted DNA was stored at $-20^{\circ} \mathrm{C}$.

\section{Chloroplast microsatellites analysis}

Due to the lack of intraspecific variation observed in Carpinus spp. we initially tested ten universal chloroplast microsatellites (ccmp1, ccmp2, ccmp3, ccmp4, ccmp5, ccmp6, cсmp7, сcmp8, сcmp9 and ccmp10) developed by Weising and Gardener (1999). Nine out of ten primers showed the amplification products, but only three primers (ccmp4, ccmp 7 and $c$ cmp 10) showed fragment length polymorphism. DNA was diluted (1:30) prior to PCR amplification. PCR reactions were performed in a total volume of $15 \mu \mathrm{l}$ of a reaction mixture consisting of $1 \times$ PCR Buffer (Promega), $2.5 \mathrm{mM} \mathrm{MgCl} 2,200 \mu \mathrm{M}$ of each of the four dNTPs, 1 unit of Taq DNA Polymerase (Promega), $0.2 \mu \mathrm{M}$ of each primer added to $2 \mu \mathrm{l}$ of genomic DNA. PCR amplifications were performed in a Corbett Palm-Cycler CG1-96 with the following conditions: an initial denaturation for 15 minutes at $95^{\circ} \mathrm{C}$ followed by $30 / 35$ cycles of denaturation for 1 minute at $94^{\circ} \mathrm{C}$, annealing for 1 minute at $50^{\circ} \mathrm{C}$, extension for 1 minute at $72^{\circ} \mathrm{C}$ and a final extension for 20 minutes at $72{ }^{\circ} \mathrm{C}$ (30 cycles for ccmp 4 and 35 cycles for $c$ cmp 7 and comp 10). The amplification of chloroplast SSRs was performed using fluorescence dyed forward primers (Metabion) for genotyping purpose, namely 6-FAM/Blue (ccmp7 and ccmp10) and HEX/Green (ccmp4).

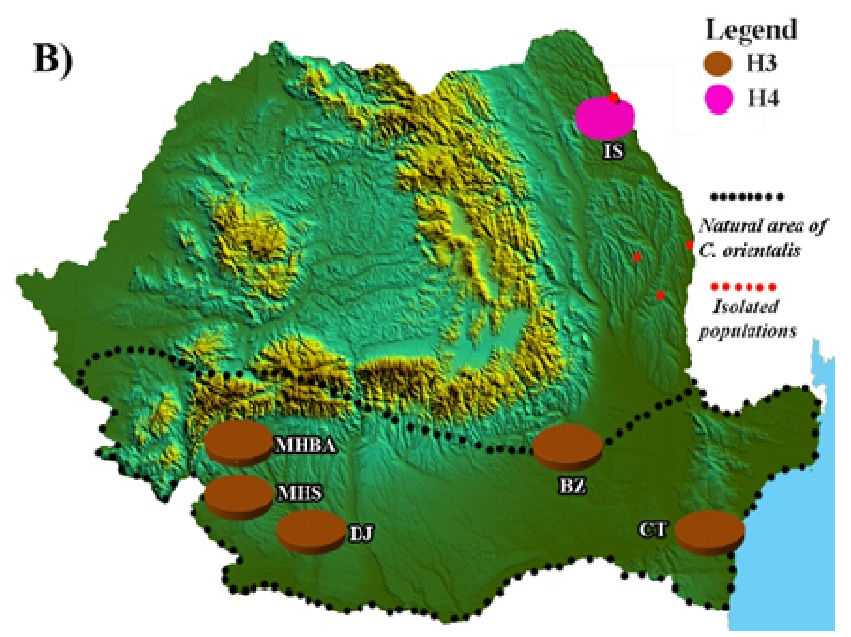

Fig. 1. Distribution of C. betulus (A) and C. orientalis (B) chloroplast DNA haplotypes in Romania 
318

Table 1. Geographic location of populations

\begin{tabular}{|c|c|c|c|c|c|c|}
\hline No & Population & Abbreviation & Latitude & Longitude & Sample size & Species \\
\hline 1 & Apa Sărată-Maramureș & MM-CB & $47^{\circ} 40^{\prime}$ & $23^{\circ} 29^{\prime}$ & 5 & \multirow{19}{*}{$\begin{array}{l}\frac{3}{3} \\
\mathbb{2} \\
ن\end{array}$} \\
\hline 2 & Teaca-Bistrița-Năsăud & $\mathrm{BN}-\mathrm{CB}$ & $46^{\circ} 52^{\prime}$ & $24^{\circ} 32^{\prime}$ & 5 & \\
\hline 3 & Roșcani-Iași & IS-CB & $47^{\circ} 26^{\prime}$ & $27^{\circ} 24^{\prime}$ & 5 & \\
\hline 4 & Panciu-Vrancea & VN-CB & $46^{\circ} 04^{\prime}$ & $27^{\circ} 01^{\prime}$ & 5 & \\
\hline 5 & Babadag-Tulcea & TLB-CB & $44^{\circ} 51^{\prime}$ & $28^{\circ} 41^{\prime}$ & 5 & \\
\hline 6 & Măcin-Tulcea & TLM-CB & $45^{\circ} 14^{\prime}$ & $28^{\circ} 11^{\prime}$ & 5 & \\
\hline 7 & Warthe-Brașov & $\mathrm{BVW}-\mathrm{CB}$ & $45^{\circ} 39^{\prime}$ & $25^{\circ} 34^{\prime}$ & 5 & \\
\hline 8 & Tâmpa-Braşov & BVT-CB & $45^{\circ} 38^{\prime}$ & $25^{\circ} 35^{\prime}$ & 5 & \\
\hline 9 & Gura Teghii-Buzău & BZGT-CB & $45^{\circ} 32^{\prime}$ & $26^{\circ} 28^{\prime}$ & 8 & \\
\hline 10 & Măgura-Buzău & BZM-CB & $45^{\circ} 16^{\prime}$ & $26^{\circ} 33^{\prime}$ & 8 & \\
\hline 11 & Colți-Buzău & BZC-CB & $45^{\circ} 22^{\prime}$ & $26^{\circ} 23^{\prime}$ & 5 & \\
\hline 12 & Lotrisor-Vâlcea & VL-CB & $45^{\circ} 17^{\prime}$ & $24^{\circ} 12^{\prime}$ & 7 & \\
\hline 13 & Leamna-Dolj & $\mathrm{DJ}-\mathrm{CB}$ & $44^{\circ} 18^{\prime}$ & $23^{\circ} 42^{\prime}$ & 5 & \\
\hline 14 & Baia de Aramă-Mehedinți & MHBA-CB & $44^{\circ} 57^{\prime}$ & $22^{\circ} 45^{\prime}$ & 5 & \\
\hline 15 & Stârmina-Mehedinți & MHS-CB & $44^{\circ} 30^{\prime}$ & $22^{\circ} 46^{\prime}$ & 3 & \\
\hline 16 & Lugoj-Timişoara & TM-CB & $45^{\circ} 42^{\prime}$ & $21^{\circ} 58^{\prime}$ & 5 & \\
\hline 17 & Săvârșin-Arad & AR-CB & $46^{\circ} 00^{\prime}$ & $22^{\circ} 13^{\prime}$ & 5 & \\
\hline \multirow[t]{2}{*}{18} & Huedin-Cluj & $\mathrm{CJ}-\mathrm{CB}$ & $46^{\circ} 56^{\prime}$ & $22^{\circ} 49^{\prime}$ & 5 & \\
\hline & & Total & & & 96 & \\
\hline 1 & Roșcani-Iași & IS-CO & $47^{\circ} 26^{\prime}$ & $27^{\circ} 24^{\prime}$ & 6 & \multirow{6}{*}{ 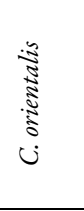 } \\
\hline 2 & Murfatlar-Constanța & CT-CO & $44^{\circ} 09^{\prime}$ & $28^{\circ} 23^{\prime}$ & 6 & \\
\hline 3 & Cândești-Buzău & $\mathrm{BZ}-\mathrm{CO}$ & $45^{\circ} 16^{\prime}$ & $26^{\circ} 40^{\prime}$ & 5 & \\
\hline 4 & Leamna-Dolj & $\mathrm{DJ}-\mathrm{CO}$ & $44^{\circ} 17^{\prime}$ & $23^{\circ} 43^{\prime}$ & 5 & \\
\hline 5 & Baia de Aramă-Mehedinți & MHBA-CO & $44^{\circ} 57^{\prime}$ & $22^{\circ} 45^{\prime}$ & 5 & \\
\hline \multirow[t]{2}{*}{6} & Stârmina-Mehedinți & MHS-CO & $44^{\circ} 29^{\prime}$ & $22^{\circ} 45^{\prime}$ & 5 & \\
\hline & & Total & & & 32 & \\
\hline
\end{tabular}

Amplified fragments were analysed on a GenomeLab GeXP Genetic Analysis System (Beckman Coulter) using an internal size standard (CEQ 400, Beckman Coulter). Polymorphisms were defined by different length variants of detected microsatellite fragments.

\section{Data analysis}

The programme PERMUT cpSSR (Pons and Petit, 1996) was used to calculate the parameters of chloroplast DNA diversity $\left(h_{S}=\right.$ haplotype diversity within populations based on unordered haplotypes, $h_{T}=$ total haplotypie diversity statistics based on unordered alleles, $G_{S T}=$ differentiation among populations based on unordered alleles and $R_{S T}=$ differentiation among populations based on ordered alleles).

A hierarchical analysis of molecular variance (AMOVA) was conducted to estimate the distribution of genetic variation among and within populations using GenAlEx version 6.5 (Peakall and Smouse, 2012). The variance components were tested statistically by non-parametric randomization tests using 999 permutations. Genetic distances (Nei, 1987) between pairs of populations were calculated with HAPLOTYPE ANALYSIS(C) version 1.05 (Eliades and Eliades, 2009).

The software SPAGEDI version 1.5 (Hardy and Vekemans, 2002) was used to test for the presence of a phylogeographic pattern by permuting allele sizes among alleles. If the observed $R_{S T}$ is higher than the $R_{S T}$ after permutations, we may infer that there is a phylogeographic pattern.

The relationships among found cpSSR haplotypes were inferred based on the median-joining network algorithm (Bandelt et al., 1999). Maximum-parsimony analysis was conducted using the software NETWORK version 5.0 (available at http://www.fluxus engineering.com/sharenet. htm). NETWORK identifies the number of mutational steps that separate a given set of haplotypes and accounts for haplotype frequency at a given node.

To evaluate the population phylogenetic relationships among populations an unweighted pair group average network (UPGMA) was constructed using Euclidean paired group algorithm of PAST software (Hammer et al., 2001). One thousand bootstrapped replicated matrices of pairwise Nei's genetic distances (1987) were calculated using the same program.

The association between the pairwise genetic distance (Nei, 1987) and geographic distances (GGD) was analyzed with Mantel test (Mantel, 1967) using GenAlEx version 6.5 software (Peakall and Smouse, 2012).

\section{Results}

\section{Chloroplast DNA haplotypes}

Following the genotyping of the 128 individuals with three cpSSRs, 8 variants were identified. Thus, only two variants (and thus haplotypes) were found in the two species, which are completely different in this analysis.

One of the three chloroplast microsatellite regions showed polymorphism in C. betulus, that displayed two size variants at $c$ cmp 7 (Table 2). The size variants from all three analyzed chloroplast microsatellites were combined into two haplotypes for $C$. betulus, with $\mathrm{H} 1$ being found in all eighteen populations, while $\mathrm{H} 2$ was found in seven populations (Fig.1.A).

In $C$. orientalis two size variants were observed at $c c m p 10$ among three analyzed microsatellite regions (Table 2). By combining size variants of chloroplast SSRs, two haplotypes were identified in six populations. Five populations of $C$. orientalis from southern Romania are monomorphic (haplotype $\mathrm{H} 3$, while haplotype $\mathrm{H} 4$ was detected only in an isolated population located in north-eastern part of Romania (Fig.1.B). 
Table 2. Observed chloroplast DNA haplotypes in C. betulus and $C$. orientalis

\begin{tabular}{|c|c|c|c|c|c|}
\hline \multirow{2}{*}{ SSR marker } & \multicolumn{2}{|c|}{ C. betulus } & \multicolumn{2}{|c|}{ C. orientalis } & \multirow{2}{*}{ No. of variants } \\
\hline & $\mathrm{H} 1$ & $\mathrm{H} 2$ & $\mathrm{H} 3$ & $\mathrm{H} 4$ & \\
\hline ccmp 4 & $118 \mathrm{bp}$ & 118 bp & $129 \mathrm{bp}$ & $129 \mathrm{bp}$ & 2 \\
\hline ccmp 7 & $158 \mathrm{bp}$ & $157 \mathrm{bp}$ & $159 \mathrm{bp}$ & $159 \mathrm{bp}$ & 3 \\
\hline ccmp10 & $110 \mathrm{bp}$ & $110 \mathrm{bp}$ & $117 \mathrm{bp}$ & $115 \mathrm{bp}$ & 3 \\
\hline No. of individuals & 79 & 17 & 26 & 6 & \\
\hline
\end{tabular}

Genetic diversity

Genetic differentiation among $C$. betulus populations was moderate $\left(G_{S T}=0.422\right.$ and $\left.R_{S T}=0.422\right)$ compared with $C$. orientalis $\left(G_{S T}=1\right.$ and $\left.R_{S T}=1\right)$ (Table 3$)$.

The analysis of molecular variance (AMOVA) for $C$. betulus showed that $42 \%$ of the haplotypic variation was due to differences among populations, whereas $58 \%$ to differences within populations. In C. betulus only 11 out of 18 populations are represented by one haplotype and 7 populations are mixed by two haplotypes with three populations significantly dominated by H2 (MM, BZC and BZGT) (Fig. 1).

The permutation test performed in SPAGEDI showed that the observed $R_{S T}$ was equal to the $R_{S T}$ after permutations, indicating an absence of a phylogeographic pattern for both species. Indeed, the dominance of two haplotypes in the Carpathians was also suggested by Postolache et al. (2017), based on the polymorphic bands observed in two combinations (atpH-atpI/Hinfl and trnCtrnD/TaqI). However, a geographic pattern of genetic variation may be observed from the haplotype frequency map in C. betulus and C. orientalis (Fig. 1). Because our study found only two variants in each of the two species, the results should be interpreted with caution.

\section{Phylogenetic relationships between haplotypes}

The genetic relationships between all haplotypes show a clear (Fig. 2) separation of haplotypes specific for $C$. betulus and those identified in C. orientalis. Within the network, $\mathrm{H} 1$ is the ancestral one and $\mathrm{H} 2$ appears to be derived from $\mathrm{H} 1$. On the other hand, $\mathrm{H} 3$ detected in $C$. orientalis most probably evolved from $\mathrm{H} 4$, however these results need to be interpreted with caution due to limited variants found.

The UPGMA dendrogram based on Nei's distances (1987) supports geographic grouping of haplotypes by species (Fig. 3). All C. betulus populations were clustered together with subsequent subclustering of populations in two groups, each group being specific for one of the two haplotypes. On the other hand, C. orientalis populations are clustered into two distinct subclusters, with one of subcluster represented by population Roşcani, in which a unique haplotype was observed for $C$. orientalis. It is also important to note that branches of the major clusters correspond to distinct geographic regions.

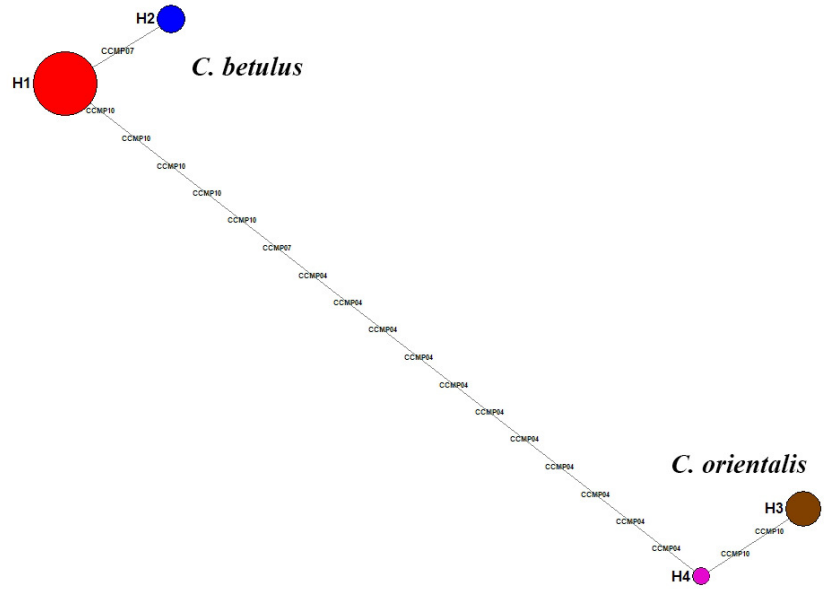

Fig. 2. Maximum parsimony phylogenetic network among four chloroplast haplotypes observed in three chloroplast SSRs loci. Size of circles corresponds to number of individuals of a given haplotype

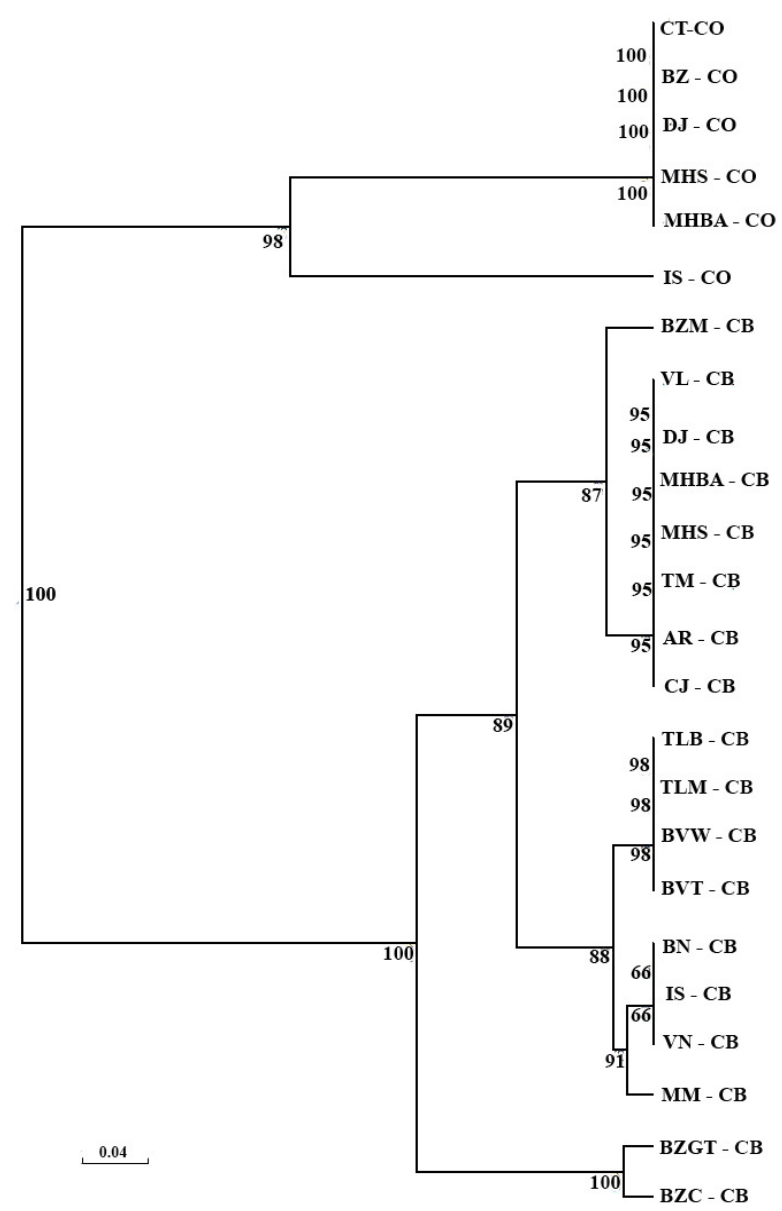

Fig. 3. UPGMA dendrogram based on genetic distances (Nei, 1983) among populations (C. betulus - CB; C. orientalis - CO)

Table 3. Levels of genetic diversity and differentiation in Carpinus spp.

\begin{tabular}{|c|c|c|c|c|c|c|}
\hline Species & $\begin{array}{c}\text { Sample } \\
\text { size }\end{array}$ & $\begin{array}{l}\text { Number of } \\
\text { haplotypes }\end{array}$ & $\begin{array}{c}\mathrm{hs} \\
(\mathrm{SE}) \\
\end{array}$ & $\begin{array}{l}\mathrm{h}_{\mathrm{T}} \\
(\mathrm{SE}) \\
\end{array}$ & $\begin{array}{l}\mathrm{G}_{\mathrm{ST}} \\
(\mathrm{SE}) \\
\end{array}$ & $\begin{array}{l}\mathrm{R}_{S T} \\
(\mathrm{SE})\end{array}$ \\
\hline C. betulus & 96 & 2 & $0.160(0.051)$ & $0.277(0.087)$ & $0.422(0.094)$ & $0.422(0.093)$ \\
\hline C. orientalis & 32 & 2 & $0.000(0.000)$ & $0.333(0.222)$ & $\begin{array}{l}1.000 \\
(\mathrm{NC})\end{array}$ & $\begin{array}{l}1.000 \\
(\mathrm{NC})\end{array}$ \\
\hline
\end{tabular}




\section{Discussion}

Our data confirmed previous results that the two Carpinus species do not share common chloroplast haplotypes (Grivet and Petit, 2003). The non-overlapping and non-sharing of haplotypes between $C$. betulus and $C$. orientalis suggest that a much more ancient separation of these two taxa occurred perhaps even before quaternary glaciations, as discussed for other related species (Hewitt, 1999). Indeed, sequences of the nuclear ribosomal internal transcribed spacer (ITS) suggest an extensive biogeographic track between southeastern Europe and eastern Asia and most importantly indicate for two distinct clades of Carpinus where $C$. betulus is grouped in a different clade than $C$. orientalis (Yoo and Wen, 2002). This result suggests that these two species have their origin in eastern Asia considered a refugium for the section Carpinus. Paleobotanic fossils of the section Carpinus have been reported for Europe from the Middle Eocene Eckfeld flora (Wilde and Frankenhäuser, 1998). Additionally, each species has a different ploidy level with $2 \mathrm{n}=8 \mathrm{x}=64$ for $C$. betulus (Petrova, 2006) and $2 \mathrm{n}=2 \mathrm{x}=16$ in $C$. orientalis (Santamour, 1995). The differentiation among $C$. orientalis populations was very high and reached a value of 1 , which is due to the fact that populations are fixed for one haplotype or another. Our data indicates fixation of haplotype H3, which was found in five out of the six populations. The high differentiation detected in $C$. orientalis populations can be explained by strong fragmentation of populations that are isolated over long distances. High values of genetic differentiation was also observed in Corylus avellana $\left(G_{S T}=\right.$ 0.89 ) with low dispersal abilities and which is member of the same family Betulaceae (Petit et al., 2003; Leinemann et al., 2013). The low values of differentiation similar to those observed in our study for $C$. betulus populations were reported for Castanea sativa $\left(G_{S T}=0.43\right.$ - Fineschi et al., $2000)$ and Betula pendula $\left(G_{S T}=0.424\right.$ - Palmé, 2003; Leinemann et al., 2013). It was estimated that, on average, the woody angiosperms present a differentiation index between populations of 0.73 (Petit, 1999). The relatively low genetic differentiation among $C$. betulus populations may be explained by historical effective seed dispersal over short but also over long distances during postglacial recolonisation (Heuertz et al., 2004).

The geographic distribution of cpDNA haplotypes in $C$. betulus reveals a phylogeographic pattern, which is comparable with a recent study on hornbeam by Postolache et al. (2017) based on PCR-RFLP analysis. Haplotype H2 is preponderant in populations located on the external side of the southeastern Carpathians arch (Gura Teghii - 75\% and Colți - 80\%). In this area, palynological analysis revealed early records of $C$. betulus at lower altitudes in the Subcarpathian region (Magyari, 2002; Willner et al., 2009). The same haplotype $\mathrm{H} 2$ was also observed in a quite distant $C$. betulus population located in the north-west part of Romania (Apa Sărată), the Maramureş region, where it has a relative frequency of $60 \%$. It is worth to mention the high frequency of $\mathrm{H} 2$ in the population (MM) from northern part of Romania and in two populations from the Curvature Carpathians (BZC and BZGT). These populations are very close to the 'suture zones' identified in the Ukrainian and in the Curvature Carpathians, which resulted as a consequence of contact between different recolonization routes (Postolache et al., 2017). Delineated postglacial recolonisation routes by Postolache et al. (2017), confirm our phylogeographic pattern and explain the observed geographic distribution of haplotypes ( $\mathrm{H} 1$ and $\mathrm{H} 2$ ).

The existence of a northern latitude refugium for $C$. betulus was previously mentioned in the seminal work of Willis (1996). Indeed, this was also suggested by Magyari (2002) who mentioned the existence of a glacial refugium for $C$. betulus in the North Hungarian Middle Mountains, based on palynological data. More recently, Mitka et al. (2014) also indicated a possible refugium in the Northern Carpathians, and raised the question of whether post-glacial recolonisation would have been plausible from this northern refugium. However, based on the recent findings (Postolache et al., 2017), we can suggest that haplotype $\mathrm{H} 2$ most probably originated in the south-eastern part of Bulgaria. The glacial refugium for haplotype $\mathrm{H} 1$ was most probably located in the mountains of Rhodope and Pirin, while the glacial refugium for $\mathrm{H} 2$ was located separately in the Strandzha Mountains, very close to the Black Sea coast. The post-glacial re-colonization routes $\mathrm{B}$ and $\mathrm{C}$ that correspond to haplotypes $\mathrm{H} 1$ and $\mathrm{H} 2$, respectively, were described in detail by Postolache et al. (2017).

The two haplotypes detected in $C$. orientalis are located in two distinct geographic areas: haplotype 3 being specific for southern part of Romania, while haplotype 4 was observed in an isolated population located at the northern limit of species range. Haplotype $\mathrm{H} 3$ is more present in the area of forested steppe lands, located in the southern part of the Carpathians and may suggest that those populations might have a common origin most probably as a result of recolonisation from southern Balkan refugia (Grivet and Petit, 2003). The presence of a distinct haplotype (H4) in the Roşcani population may be explained by a different glacial refugium origin. Based on this finding we may suggest that Roşcani population deserve high priority for conservation and can be included in the genetic resources of this species. Interestingly, haplotype $\mathrm{H} 4$ that was identified 200 kilometres farther north than the nearest southern $C$. orientalis populations (Jideni, Ramnicu Sărat). Isolated $C$. orientalis populations are also found in Vaslui (Bogdana, Lupesti, Stănileşti) (Chifu et al., 2006), at a distance of 100$110 \mathrm{~km}$ from Roşcani population, therefore this population would deserve more attention in future studies with both chloroplast and nuclear SSRs. Roşcani population that harbour haplotype $\mathrm{H} 4$ consists of a small number of trees, that was possibly larger in the past although there is no evidence of recent bottleneck (based on nSSRs analysis (data not shown). The origin of this unique haplotype is difficult to be explained, but it is worth to mention that this C. orientalis population is located at the limit of species natural distribution range in highly fragmented habitats.

Previous studies have also shown that $C$. betulus populations from Romania harbour outstanding genetic polymorphism compared with western European populations (Grivet and Petit, 2003). Indeed, we observed seven polymorphic $C$. betulus populations, out of 18 , using 
only three cpSSR markers. All six populations of $C$. orientalis are fixed for one of the two detected haplotype. To our knowledge, this is the first study on $C$. orientalis genetic structure of populations from Romania. The small number of observed haplotypes in both species may suggest that only few glacial refugia of Carpinus species have existed in southern Balkans during the Late Glacial Maximum (LGM). We may thus expect that populations of Carpinus species from southern Balkans may harbour unique haplotypes, which was confirmed in a recent study (Postolache et al., 2017), but those populations did not succeed to expand and to migrate because of tough competition with early successional trees species (Grivet and Petit, 2003). Additionally, the high heterogeneity of mountain landscape across Balkan Peninsula may hinder expansion northwards of Carpinus species. Reduced genetic chloroplast DNA variation was also observed in beech (Demesure et al., 1996), which is also considered a latesuccessional tree species and also in hazel (Palmé, 2002; Leinemann et al., 2013). Most of these studies suggest that long glacial episodes have a profound effect on geographic organization of chloroplast DNA variation. The analysis of chloroplast genome in two Carpinus species (C. betulus and C. orientalis) revealed a distinct geographic distribution of cpDNA haplotypes, which emphasize that hornbeam forests have undergone idiosyncratic postglacial migration. The interspecific phylogeography of Carpinus spp. succeeded to reveal hornbeam populations with peculiar genetic structure (e.g. Roşcani), which may have important consequences on the management and conservation of Carpinus spp. genetic resources in Romania.

\section{Conclusions}

Only a limited number of chloroplast haplotypes was observed in both Carpinus species across Romania. The geographic distribution of chloroplast haplotypes suggests that Carpathian Mountains may have played an important role during the Holocene postglacial recolonization history of Carpinus species. Our study confirms that both Carpinus species do not share common haplotypes, which may suggest a much more ancient separation of these two taxa. A very rare chloroplast DNA haplotype was identified in an isolated peripheral population of $C$. orientalis, which deserve a high priority for conservation. The geographic structure of chloroplast genetic variation in Carpinus species appears to be primarily a reflection of past (postglacial) migration history, whereas more recent adaptive and stochastic processes have occurred at more local scales.

\section{Acknowledgements}

We wish to thank four anonymous reviewers for helpful comments on an earlier version of the manuscript.

\section{References}

Bandelt HJ, Forster P, Rohl A (1999). Median-joining networks for inferring intraspecific phylogenies. Molecular Biology and Evolution 16:37-48.
Bergmeier E, Dimopoulos P (2008). Identifying plant communities of thermophilous deciduous forest in Greece: species composition, distribution, ecology and syntaxonomy. Plant Biosystems 142:228254.

Čarni A, Košir P, Karadžić B, Matevski V, Redžić S, Škvorc Ž (2009). Thermophilous deciduous forests in Southeastern Europe. Plant Biosystems 143:1-13.

Chifu T, Mânzu C, Zamfirescu O (2006). Flora şi vegetația Moldovei. Univ. “Al. I. Cuza” Iaşi, pp 42 (in Romanian).

Demesure B, Comps B, Petit RJ (1996). Chloroplast DNA phylogeography of the common beech (Fagus sylvatica L.) in Europe. Evolution 50:2515-2520.

Doyle JJ, Doyle JL (1987). A rapid DNA isolation procedure for small quantities of fresh leaf tissue. Phytochemical Bulletin 19:11-15.

Eliades N-GH, Eliades DG (2009). HAPLOTYPE ANALYSIS: Software for analysis of haplotype data. Distributed by the authors. Forest Genetics and Forest Tree Breeding, Georg-August University Goettingen, Germany.

Fărcaş S, Popescu F, Tantau I (2006). Spatial and temporal distribution of pedunculate oak, common ash and hornbeam during late glacial and postglacial period in Romania. Editura Presa Universitara Clujeana (in Romanian).

Fineschi S, Taurchini D, Villani F, Vendramin GG (2000). Chloroplast DNA polymorphism reveals little geographical structure in Castanea sativa Mill. (Fagaceae) throughout southern European countries. Molecular Ecology 9:1495-1503.

Grivet D, Petit R (2003). Chloroplast DNA phylogeography of the hornbeam in Europe: Evidence for a bottleneck at the outset of postglacial colonization. Conservation Genetics 4:47-53.

Hammer Ø, Harperm DAT, Ryan PD (2001). PAST: Paleontological Statistics Software Package for education and data analysis. Palaeontolia Electronica 4:1-9.

Hardy OJ, Vekemans X (2002). SPAGeDi: a versatile computer program to analyse spatial genetic structure at the individual or population levels. Molecular Ecology Notes 2:618-620.

Heuertz M, Fineschi S, Anzidei M, Pastorelli R, Salvini D, Paule L, ... Vendramin G (2004). Chloroplast DNA variation and postglacial recolonization of common ash (Fraxinus excelsior L.) in Europe. Molecular Ecology 13:3437-3452.

Hewitt GM (1999). Post-glacial re-colonization of European biota. Biological Journal of the Linnean Society 68:87-112.

Horeanu C (1996). Dendrologie. Universitatea "Ştefan cel Mare" Suceava, Facultatea de Silvicultură (in Romanian).

IFN (2012). National Forest Inventory, Romania. Retrieved 2012 Dec 11 from http://lemn.fordaq.com/news/paduri_suprafata_volum_crestere_ 44662.html.

Leinemann L, Steiner W, Hosius B, Kuchma O, Arenhövel W, Fussi B, ... Finkeldey R (2013). Genetic variation of chloroplast and nuclear markers in natural populations of hazelnut (Corylus avellana L.) in Germany. Plant Systematics and Evolution 299(2):369-378.

Magyari E (2002). Holocene biogeography of Fagus sylvatica L. and Carpinus betulus L. in the Carpathian-Alpine Region. Folia Historico-Naturalia Musei Matraensis 26:15-35. 
322

Mantel NA (1967). The detection of disease clustering and a generalized regression approach. Cancer Research 27:209-220.

Mitka J, Bąba W, Szczepanek K (2014). Putative forest glacial refugia in the Western and Eastern Carpathians. Modern Phytomorphology 5:85-92.

Nei M (1983). Genetic polymorphism and the role of mutation in evolution. In: Evolution of genes and proteins 71:165-190.

Ortiz-Ramírez MF, Andersen MJ, Zaldívar-Riverón A, Ornelas JF, Navarro-Sigüenza AG (2016). Geographic isolation drives divergence of uncorrelated genetic and song variation in the Ruddycapped Nightingale-Thrush (Catharus frantzii; Aves: Turdidae). Molecular Phylogenetics and Evolution 94:74-86.

Palmé A (2003). Evolutionary history and chloroplast DNA variation in three plant genera: Betula, Corylus and Salix: The impact of postglacial colonisation and hybridisation. Acta Universitatis Upsaliensis. Comprehensive Summaries of Uppsala Dissertations from the Faculty of Science and Technology, Uppsala 795.

Palmé AE (2002). Chloroplast DNA variation, postglacial recolonization and hybridization in hazel, Corylus avellana. Molecular Ecology 11:1769-1779.

Peakall R, Smouse PE (2012). GenAlEx 6.5: genetic analysis in Excel. Population genetic software for teaching and research-an update. Bioinforma Oxford England 28:2537-2539.

Petit RJ (1999). Diversité génétique et histoire des populations d'arbres forestiers. Dossier d'habilitation à diriger des recherches, Université de Paris-Sud, Université formation de recherche Scientifique d'Orsay, Paris.

Petit RJ, Aguinagalde I, Jacques-Louis de Beaulieu, Bittkau C, Brewer S, Cheddadi R, ... Vendramin GG (2003). Glacial refugia: hotspots but not melting pots of genetic diversity. Science 300:1563-1565.

Petit RJ, Duminil J, Fineschi S, Hampe A, Salvini D, Vendramin GG (2005). Comparative organization of chloroplast, mitochondrial and nuclear diversity in plant populations. Molecular Biology and Evolution 14:689-701.

Petre M, Nicolescu VN, Ghirda B (2012). Competition and natural mortality in two mixed sessile oak (Quercus petraea (Matte.) Liebl.) dominated stands. Spanish Journal of Rural Development 4:41-50.
Petrova A (2006). Mediterranean chromosome number reports 16 (1584-1603). Flora Mediterrane 16:431-435.

Pons O, Petit RJ (1996). Measuring and testing genetic differentiation with ordered versus unordered alleles. Genetics 144:1237-1245.

Postolache D, Popescu F, Paule L, Ballian D, Zhelev P, Fărcaş S, Paule L, Badea $\mathrm{O}$ (2017). Unique postglacial evolution of the hornbeam (Carpinus betulus L.) in the Carpathians and the Balkan Peninsula revealed by chloroplast DNA. Science of the Total Environment 599:1493-1502.

Santamour FS (1995). Survival, growth, and fertility of Carpinus hybrids. Horticultural Science 30(6):1151-1192.

Şofletea N, Curtu L (2007). Dendrologie. Editura Universităţii Transilvania, Braşov. 182-187 (in Romanian).

Weising K, Gardner RC (1999). A set of conserved PCR primers for the analysis of simple sequence repeat polymorphisms in chloroplast genomes of dicotyledonous angiosperms. Genome 42:9-19.

White TL, Adams WT, Neale DB (2007). Forest Genetics. CAB International.

Wilde V, Frankenhäuser H (1998). The Middle Eocene plant taphocoenosis from Eckfeld (Eifel, Germany). Review of Palaeobotany and Palynology 101:7-28.

Willis KJ (1996). Where did all the flowers go? The fate of temperate European flora during glacial periods. Endeavour 20:110-114.

Willner W, Di Pietro R, Bergmeier E (2009). Phytogeographical evidence for post-glacial dispersal limitation of European beech forest species. Ecography 32:1011-1018.

Xu J, Deng M, Jiang XL, Westwood M, Gang Song Y, Turkington R (2015). Phylogeography of Quercus glauca (Fagaceae), a dominant tree of East Asian subtropical evergreen forests, based on three chloroplast DNA interspace sequences. Tree Genetics and Genomes 11:1-17.

Yoo K-O, Wen J (2002). Phylogeny and biogeography of Carpinus and subfamily Coryloideae (Betulaceae). International Journal of Plant Sciences 163:641-650. 